\title{
EFFECTIVENESS OF USE OF COOPERATIVE LEARNING MODELS OF NUMBERED HEAD TOGETHER (NHT) TYPE AND TYPE OF THINK PAIR SHARE (TPS) ON MATHEMATICAL LEARNING OUTCOMES OF SMP MUHAMMADIYAH 1 YOGYAKARTA
}

\author{
Ade Prayoga a , Sumargiyani ${ }^{\mathrm{b}}$ \\ Program Studi Pendidikan Matematika Universitas Ahmad Dahlan \\ Jalan Ring Road Selatan, Tamanan, Banguntapan, Bantul Yogyakarta \\ adepravoga28@gmail.com, ${ }^{\text {, }}$ sumargivani04@yahoo.com
}

\begin{abstract}
Learning mathematics in class VII of SMP Muhammadiyah 1 Yogyakarta in the 2015/2016 academic year still uses conventional methods that result in students who are less enthusiastic about learning mathematics. The use of inappropriate learning models makes students less familiar with the material explained by the teacher and results in low mathematics learning outcomes. The population in this study were VII grade students of SMP Muhammadiyah 1 Yogyakarta which consisted of 3 classes. Samples of 2 classes with a total of 67 students were taken by random sampling technique for the class obtained VII F as the experimental class A and class VII E as the experimental class B. The research instrument was a test of learning outcomes. Data analysis uses party testing and a one-party t-test. Based on the analysis of the first hypothesis test on mathematics learning outcomes with a significant level of $5 \%$ and 65 degrees of freedom obtained by $t_{\text {count }}=8.12>t_{\text {table }}=1,999$, it shows that there are significant differences between mathematics learning outcomes using NHT type cooperative learning models and those using models TPS type of cooperative learning, and the second test with a significant level of 5\% and 65 degrees of freedom obtained by $t_{\text {countt }}=8.12>t_{\text {table }}=1.66$ indicates that the cooperative learning model NHT type is more effective than the TPS cooperative learning model in improving mathematics learning outcomes students.
\end{abstract}

Keywords: Effectiveness, Cooperative type NHT, Cooperative type of TPS, Learning Outcomes.

\section{INTRODUCTION}

Education is very important in life, this means that every human being has the right to education. Education is not only obtained as long as someone studies in a formal education institution, but education can be obtained by someone through family education and the environment in the form of independent learning activities. With education, it is hoped that the next generation will emerge that is qualified and able to adapt to live in a society, nation, and state. The teacher has an important role in realizing the goals of mathematics learning. A teacher must be able to create situations and conditions that enable active learning. One of them is by paying attention to the learning method or strategy used. The choice of method must be adjusted to the teaching objectives, teaching material, and the form of teaching. Therefore in teaching can be used various methods that are by what is taught. The learning model chosen by the teacher should be a learning model that can attract the attention of students to be more active in learning, especially mathematics. Therefore, mathematics lessons should be sought to be interesting and fun lessons. One interesting learning model and increasing the interactive intensity of students is cooperative learning. Cooperative learning can be done by dividing students into small groups to carry out activities together. Not only that, but the cooperative learning model also requires student collaboration and interdependence in the structure of tasks, goals, and rewards. Various types of cooperative learning models can be used by teachers, including the Numbered Head Together (NHT) type, and Think Pair Share (TPS).

The problems in this study are: 1) Is there a significant difference between the mathematics learning outcomes using the cooperative learning type NHT model, using the TPS cooperative learning model in class VII of the odd semester of SMP Muhammadiyah 1 Yogyakarta academic year 2015/2016. 2) Is the NHT type of cooperative learning model more effective than the TPS type cooperative learning 
model for mathematics learning outcomes in class VII odd semester SMP Muhammadiyah 1 in the academic year 2015/2016?.

The objectives of this study were: 1) To find out whether there was a significant difference between the mathematics learning outcomes using the cooperative learning type NHT model and the type of polling station in the seventh-semester students of SMP Muhammadiyah 1 Yogyakarta academic year 2015/2016. 2) To find out whether the cooperative learning model of the NHT type is more effective than the TPS type cooperative learning model on the learning outcomes of mathematics in class VII odd semester students of SMP Muhammadiyah 1 Yogyakarta Academic Year 2015/2016.

\section{THEORY}

Mathematics is a subject that has material related to the next material. So that learning mathematics must understand the material well before continuing the material, as revealed by Hamzah B Uno (1111: 130) that the nature of learning mathematics is mental activity to understand the meaning and relationships and symbols, then applied to real situations. According to Winkel in Purwanto (2011: 45) said that learning outcomes are changes that result in humans changing attitudes and behavior, aspects of change that refers to the taxonomy of teaching goals developed by Bloom, Simpson, and Harrow covering cognitive, affective, and psychomotor aspects.

Numbered Heads Together (NHT) is one type of cooperative learning characterized by numbering all students in each group. According to Slavin in Miftahul Huda (2014: 203), states that the method developed by Russ Frank (NHT) is suitable for ensuring individual accountability in group discussions. NHT aims to allow students to share ideas in considering the most appropriate answers. The following are NHT steps that researchers are doing: 1) The teacher gives the material briefly as an introduction. 2) Students are divided into several groups. 3) Each student in the group is numbered. 4) The teacher gives assignments or questions and each group does it. 5) Each group discusses the correct answers to the questions given by the teacher and ensures that each group member can work on and know the answers. 6) The teacher randomly calls the number of students and the student who is called presents the answers to the group in front of the class. 7) Responses from other groups. 8) Conclusion.

Think Pair Share (TPS) is one type of cooperative learning that requires students to work together in pairs. According to Aris Shoimin (2014: 208), states that: Think Pair Share is a cooperative learning model that gives students time to think and respond and help each other. The purpose of TPS learning is to train students to be brave in their opinions and respect the opinions of friends. The following are the stages of the cooperative learning type TPS model that researchers do: 1) Think. 2) Pair. 3) Share.

\section{METHODS}

This type of research uses a form of experimental design in the form of True Experimental Design with a posttest only control design (Sugiyono, 2012: 112). In this study using two classes, namely experimental class I and experimental class II. In the experimental class I, learning was carried out using the cooperative type NHT learning model and in the experimental class, II learning was carried out using the TPS cooperative learning model.

The population in this study were all seventh-grade students of SMP Muhammadiyah 1 Yogyakarta Academic Year 2015/2016 which amounted to 208 students. While the samples in this study were class VII F as the experimental class I and class VII E as the experimental class II, the sampling technique used was Random Sampling. The data analysis technique used is a test technique with instruments in the form of multiple-choice objective questions. Test of prerequisite analysis by testing the normality of the Chi-square formula and homogeneity test using Bartlett. The research hypothesis test uses the first hypothesis test and the second hypothesis. Test the first hypothesis using the two-party t-test conducted to find out there is a significant difference between the learning outcomes of mathematics using the NHT type cooperative learning model with the type of TPS. While the second hypothesis test using a t-test one party was conducted to find out the cooperative learning model of the NHT type was more effective than the TPS type cooperative learning model on student learning outcomes. 


\section{RESULTS}

\section{Early Ability}

The summary results of the normal ability normality test can be seen in Table 1 .

Table 1. Summary of Initial Capability Test Results

\begin{tabular}{ccc}
\hline Class & $\chi_{\text {count }}^{2}$ & $\chi_{\text {table }}^{2}$ \\
\hline Experiment I & 5,7406 & 9,4877 \\
Experiment II & 5,8261 & 7,8147 \\
\hline
\end{tabular}

From the normality test at a significant level of $5 \%$ and the degree of freedom $=3$, it can be seen that $\chi_{\text {count }}^{2}=5,7406$ and $\chi_{\text {table }}^{2}=9,4877$ so that $\chi_{\text {count }}^{2}<\chi_{\text {table }}^{2}$ which means that the experimental class I have initial ability data that are normally distributed. While the normality test at a significant level of $5 \%$ and the degree of freedom $=3$, it can be seen that $\chi_{\text {count }}^{2}=5,8261$ and $\chi_{\text {table }}^{2}=7,8147$ so that $\chi_{\text {count }}^{2}<\chi_{\text {table }}^{2}$ which means the experimental class II has initial ability data that are normally distributed.

The summary of the results of the initial homogeneity test can be seen in Table 2 .

Table 2. Summary of Initial Ability Value Homogeneity Test Results

\begin{tabular}{cc}
\hline$\chi_{\text {count }}^{2}$ & $\chi_{\text {table }}^{2}$ \\
\hline $\mathbf{0 , 0 0 6 3 3 7 4 9}$ & 3,8415 \\
\hline
\end{tabular}

From the homogeneity test at a significant level of 5\% and the degree of freedom $=1$, it can be seen that $\chi_{\text {count }}^{2}=0,00633749$ and $\chi_{\text {table }}^{2}=3,8415$ so that $\chi_{\text {count }}^{2}<\chi_{\text {table }}^{2}$ which means both classes have the same variance (homogeneous).

The summary of the results of the first hypothesis test of the initial capability data can be seen in Table 3 .

Table 3. Summary of Results of the First Hypothesis Test of Initial Capability Value

\begin{tabular}{cc}
\hline $\boldsymbol{t}_{\text {count }}$ & $\boldsymbol{t}_{\text {table }}$ \\
\hline $\mathbf{0 , 3 5 3 6}$ & 1,999 \\
\hline
\end{tabular}

From the first hypothesis test at a significant level of 5\% and the degree of freedom $=65$, it can be seen that $\boldsymbol{t}_{\text {count }}=0,3536$ and $\boldsymbol{t}_{\text {table }}=1,999$ so that $\boldsymbol{t}_{\text {count }}<\boldsymbol{t}_{\text {table }}$ which means there is no difference between the initial ability of students using the NHT type cooperative learning model and the initial ability of students using TPS type cooperative learning models in VII grade students of Odd Semester SMP Muhammadiyah 1Yogyakarta 2015/2016 Academic Year.

\section{Mathematics Learning Outcomes}

The summary of the normality of mathematics learning outcomes can be seen in Table 4 .

Table 4. Summary of Normality Test Results Mathematics Learning Outcomes

\begin{tabular}{ccc}
\hline Class & $\chi_{\text {count }}^{\mathbf{2}}$ & $\chi_{\text {table }}^{\mathbf{2}}$ \\
\hline Experiment I & 3,9747 & 7,8147 \\
Experiment II & 6,59027 & 7,8147 \\
\hline
\end{tabular}

From the normality test at a significant level of $5 \%$ and degrees of freedom $=3$, it can be seen that $\chi_{\text {count }}^{2}=3,9747$ and $\chi_{\text {table }}^{2}=7,8147$ so that $\chi_{\text {count }}^{2}<\chi_{\text {table }}^{2}$ which means that the experimental class I has mathematical learning outcomes data that are normally distributed. While the normality test is at a significant level of $5 \%$ and the degree of freedom $=3$, it can be seen that 
$\chi_{\text {count }}^{2}=6,59027$ and $\chi_{\text {table }}^{2}=7,8147$ so that $\chi_{\text {count }}^{2}<\chi_{\text {table }}^{2}$ which means that the experimental class II has mathematical learning outcomes data that are normally distributed.

The summary of the results of the initial ability homogeneity test can be seen in Table 5 .

Table 5. Summary of Homogeneity Test Results Mathematics Learning Outcomes

\begin{tabular}{cc}
\hline$\chi_{\text {count }}^{2}$ & $\chi_{\text {table }}^{2}$ \\
\hline $\mathbf{3 , 1 9 6 2}$ & 3.8415 \\
\hline
\end{tabular}

From the homogeneity test at the 5\% significance level and the degree of freedom $=1$, it can be seen that $\chi_{\text {count }}^{2}=3,1962$ and $\chi_{\text {table }}^{2}=3,8415$ so that $\chi_{\text {count }}^{2}<\chi_{\text {table }}^{2}$ which means that the learning outcomes of both classes have the same variance (homogeneous).

The summary of the results of the first hypothesis test data on the value of mathematics learning outcomes can be seen in Table 6 .

Table 6. Summary of First Hypothesis Test Results Learning Outcomes Value

\begin{tabular}{cc}
$\boldsymbol{t}_{\text {count }}$ & $\boldsymbol{t}_{\text {table }}$ \\
\hline $\mathbf{8 , 1 2}$ & 1,999 \\
\hline
\end{tabular}

From the first hypothesis test at a significant level of $5 \%$ and degrees of freedom $=65$, it can be seen that $t_{\text {count }}=8,12$ and $t_{\text {table }}=1,99962$ so that $t_{\text {count }}>t_{\text {table }}$ This means there is a significant difference between mathematics learning outcomes using the NHT type cooperative learning model and those using the TPS type cooperative learning model in class VII students of the odd semester of SMP Muhammadiyah 1 Yogyakarta 2015/2016 Academic Year.

The summary of the results of the second hypothesis test data on the value of mathematics learning outcomes can be seen in Table 7.

Table 7. Summary of Second Hypothesis Test Results in Learning Outcomes

\begin{tabular}{cc}
\hline $\boldsymbol{t}_{\text {count }}$ & $\boldsymbol{t}_{\text {table }}$ \\
\hline $\mathbf{8 , 1 2}$ & 1,66 \\
\hline
\end{tabular}

From the second hypothesis test at a significant level of 5\% and degrees of freedom $=65$, it can be seen that $t_{\text {stat }}=8,12$ and $t_{\text {table }}=1,66$ so that $t_{\text {count }}>t_{\text {table }}$ which means that the NHT type cooperative learning model is more effective than the TPS type cooperative learning model on the learning outcomes of class VII students in odd semester of SMP Muhammadiyah 1 Yogyakarta in 2015/2016 Academic Year.

\section{CONCLUSION}

Based on the analysis of the experimental data and its discussion, this activity concludes the following:

1. There is a significant difference between mathematics learning outcomes using the NHT type cooperative learning model and those using the TPS type cooperative learning model in class VII students of the odd semester of SMP Muhammadiyah 1 Yogyakarta 2015/2016 Academic Year. This is indicated by the results of the two-party hypothesis test with a significant level of $5 \%$ and a degree of freedom 65 , obtained values $t_{\text {count }}=8,12>t_{\text {table }}=1,999$. So $\mathrm{H}_{0}$ is rejected and $\mathrm{H}_{1}$ is accepted.

2. The NHT type of cooperative learning model is more effective than the TPS type of cooperative learning model of the mathematics learning outcomes of grade VII odd semester students of SMP Muhammadiyah 1 Yogyakarta 2015/2016 Academic Year. This is indicated by the results of the one-party hypothesis test with a significant level of $5 \%$ and a degree of freedom 65 , obtained values $t_{\text {count }}=8,12>t_{\text {table }}=1,66$. So $\mathrm{H}_{0}$ is rejected and $\mathrm{H}_{1}$ is accepted. 


\section{REFERENCES}

Aris Shoimin. 2014. 68 Model Pembelajaran Inovatif dalam Kurikulum 2013. Yogyakarta : Ar-Ruzz Media.

Hamzah B Uno. 2011. Model Pembelajaran Menciptakan Proses Belajar Mengajar yang Kreatif dan Efektif. Jakarta: Bumi Aksara.

Miftahul Huda. 2014. Model-model Pengajaran dan Pembelajaran. Yogyakarta: Pustaka Pelajar. Purwanto. 2011. Evaluasi hasil Belajar. Jakarta: Pustaka Pelajar.

Sugiyono. 2012. Metode Penelitian Pendidikan (Pendekatan kuantitat if, kualitatif, dan R\&D). Bandung: Alfabeta. 